\title{
AMELIORATION OF SALT AFFECTED SOILS AND ITS PRODUCTIVITY USING SOIL AMENDMENTS AND TILLAGE SYSTEM
}

\author{
T.H.M.A. Deshesh \\ Soils, Water and Environment Res. Inst. (SWERI), Agricultural Research Center (ARC), \\ Giza, Egypt
}

Received: Feb. 15, 2021

Accepted: Mar. 7, 2021

\begin{abstract}
Ameliorating the of salt affected soils, represent an important target in the agricultural security program of Egypt. In this concern a field experiment was conducted at El-Rowad Village, South of El-Hosainiya Plain, Sharkia Governorate, Egypt, during two successive growing winter seasons 2016/ 2017 and 2017/2018 to evaluate the effect of different amendments with different two tillage systems on some properties of salt affected soils and its wheat production (Triticum aestivum) (Sakha 93). The experimental design was laid out in split- split plot with three replicates. The amendments were uniformly spread on soil surface and thoroughly mixed in the soil before sowing. This experiment was also carried under two tillage systems conservational and deep. The most important results can be summarized as follows: The effect of the conservational tillage and deep tillage with the addition amendment treatments, reduced bulk density, penetration resistances, decreased acidity, salinity and exchangeable sodium percent (ESP). On the contrary, increase the values of total porosity, hydraulic conductivity, organic matter, Grain yield, straw, total and harvest index. The achieved amelioration in physio-chemical and hydrological properties of the studied soil positively reflected on the increases of grain yields of crop wheat. Generally, it can be concluded that deep tillage, fine sawdust had decreased the hazardous effect of salinity of soil and hence exerted favorable effects on growth and yield of wheat. Finally, the obtained results suggest that this work is considered as scientific and logic fundamental base for a successful agricultural development of such salt affected area as well as possible to increase unite area income
\end{abstract}

Key words: Salt-affected soil, Clay soil, Soil properties, Tillage, Soil amendments.

\section{INTRODUCTION}

Salt affected soils are a major environmental factor limiting the productivity of agricultural lands. Soil salinity causes land degradation and affects food production, therefore, the problem of salt-affected soils has gained ever increasing important in science, technology, ecology, and economics alike during the last decades (Begum and Khan, 2013).

Soil salinization is a major environmental hazard that limits agricultural potential and is closely linked to agricultural mismanagement and water resources over exploitation, especially in arid climates (Julian et al. 2019). In Egypt are located in the northern-central part of the Nile Delta and on its eastern and western sides. However, $55 \%$ of the cultivated lands of northern Delta region are salt-affected soils, twenty percent of the southern Delta and middle Egypt region are saltaffected soils. (Ouda and Zohry 2016) showed that about 2.4 Meag fed $^{-1}$ of the total irrigated agricultural lands in Egypt are salt-affected soils Negm, (2017). Salt affected soils include saline non-sodic, saline-sodic, and non-saline sodic soils. The soil degradation in Sahl El-Hosainiya 
region is caused by salinization and sodification, (Osman et al. 2016).

So, cultivation of Salt-affected soils faces many challenges, such as poor structure, surface crusting, low water infiltration, low hydraulic conductivity, and low bulk density (Dodd et al. 2013), consequently delaying seedling emergence and restrict plant roots penetration in the sodic and saline-saltaffected soils (Worku, 2015). Whoever, a reduced amount of water and nutrients available of the plant, and specific ion effects $\mathrm{Na}^{+}$and $\mathrm{Cl}^{-1}$ leads to decrease the plant's ability to absorb water and essential nutrients for growth and thus reduction of plant growth and yield, can be causing wilt of plants although soil moisture is suitable (Norton and Strom 2012). Increased physiological stress and predisposing plants against diseases and pests ( $\mathrm{Li}$ et al. 2006). Furthermore, the application of amendments for saltaffected soils reclamation could be a beneficial practice of remediating the adverse impacts of soil sodicity as it prompts the solubilization of calcium from calcite and other Ca-carrying minerals via enhancing microbial decomposition and organic acids. (Choudhary et al. 2017) showed affecting moisture storage in soil, consequently, will affect water saving indicated that, rice straw could be the suitable practice to conserve soil moisture and obtain a higher crop yield.

General, the pH in salt-affected soils can be reduced by using chemical amendments such as elemental sulfur, but may only be effective for a relatively short amount of time due to the soil buffering capacity, where $\mathrm{CaCO}_{3}$ consistently buffers soil to $\mathrm{pH}$ values near (Mc Cauley et al. 2017). Other chemical as gypsum plays a significant role in the reclamation of saline-sodic soils by providing a $\mathrm{Ca}^{+2}$ cation to replace the exchangeable $\mathrm{Na}^{+}$from the colloid's cation exchange positions and leaching it out from the root zone into groundwater (Sharma and Minhas, 2005). Using gypsum can be used as direct source for $\mathrm{Ca}^{+2}$ action; however gypsum are normally available and relatively cheap. (Abd El-Hamid et al. 2011) concluded that the usage of any amendments such as gypsum could be positively effect on about reclamation of saline clay soil in Shall El-Tina district.

Mohamedin et al. (2005). found that, the higher efficiency of the gypsum is reflected in the fastest reductions of the $\mathrm{ECe}, \mathrm{Na}$, and SAR values in the leachates of the acid- mended soil. (Hussain et al. 2001) found that sulfur is more effective in decreased $\mathrm{ECe}$, bulk density and sodium adsorption ratio and increased total porosity and hydraulic conductivity of saline sodic soils.

Sulfur and gypsum plays a significant role in the reclamation of saline-sodic soils by providing a $\mathrm{Ca}^{2+}$ cation to replace the exchangeable $\mathrm{Na}^{+}$from the colloid's cation exchange positions and leaching it out from the root zone into ground water (Sharma and Minhas, 2005).

The role of fine sawdust and rice straw are used as amendments taken to compare the effect of tow forms of natural organic amendments nontraditional applied to soils, the addition of the agricultural wastes sush as fine sawdust, rice straw to the soil has a significant role in improving the chemical properties of soil unprofitable uses and till now has not been used in the other products. Rice straw has become a very serious problem in Egypt due to the huge production of straw of about 20 million tons year ${ }^{-1}$ Toufiq (2018). (Abd El-Halim and El- Baroudy, 2014) found that, the fine sawdust is considered as one of agricultural wastes, obtained from a lumber sawmills, and till now, have very few profitable uses. Fine sawdust may be disadvantage and desirable use as soil 
conditioner because of its slow rate of decomposition and on the other site, its benefits in improving physical properties of the soil. (Mahmoud et al. 2009) and (Lakdhar et al. 2009) reported that, the use of organic amendments fine sawdust and rice straw are improves soil structure through enhancing soil aggregation by restore soil microbial and enzymatic activities.

Physical and chemical properties of soil can be improved by applying organic amendments, which in turn leads to increase the crop yields (Yan et al. 2015). Ahmed (2018) reported that the use rice straw and fine sawdust improvement some physical-chemical soil properties, and crop productivity Emad (2019) reported that the organic amendments were most effectively to reduced exchangeable sodium percent (ESP) and soil $\mathrm{pH}$; while enhanced soil organic matter, and corn germination percentages, compare to gypsum and control. Spent grain was the most effective amendment in reducing soil sodicity and enhancing soil fertility and corn germination in the sodic soils.

Tillage systems are basically evaluated in two categories: conservational tillage systems. It is mentioned that conservational tillage can offers more protection against soil degradation and more improvement in quality of soil (Lampurlanes et al. 2001).

Therefore, an efficient (Aiad, 2012) reported that tillage system is an important factor to improve these soils to be suitable for crop production in the short time with low cost. Sub soiling (deep tillage) will enhance downward movement of irrigation water carrying off excess salts from surface layers. Adverse physical properties, low water permeability, osmotic effect, ionic imbalance and specific ion toxicity are the main harmful salinity and sodicity effects which inhibit plant growth and development (Chen et al. 2010). This may also accelerate the leaching of sodium from the subsoil thereby further reducing the possibility of reformation of the hardpan.

Deep tillage is considered as an intermediate system between surface drainage and subsurface drainage have positive effects at heavy clay salt affected soils (El-Sabry et al. 1992).

The objectives of the presented study to evaluate the effect of applied organic amendment (fine sawdust and rice straw), chemical amendments (sulfur and gypsum) and the different two tillage systems (conventional tillage and deep tillage) on improving some properties of salt affected soils and its productivity of wheat plant.

\section{MATERIALS AND METHODS}

Two seasons experiment was conducted in clay saline soil, at El-Rowad Village, South of El-Hosainiya Plain, Sharkia Governorate, Egypt, located at $31^{\circ} 812.41^{\prime \prime} \mathrm{N}$ latitude and $31^{\circ} 5215.46$ $E$ Longitude during two successive seasons of winter 2016 and 2017 and winter 2017/2018 to study the both effect of soil amendments i.e, rice straw, fine sawdust, sulfur and gypsum cambered with two tillage systems on some soil properties of saline soil and its productivity of wheat yield (Triticum aestivum) (Sakha 93) winter season, the experiment was carried out in a split-split plot design with three replicates. The main plots were two tillage systems. i.e. conventional tillage (T1) and deep tillage (T2), while the sub plots of three chemical amendments represent the i.e. gypsum requirement control (A1), Gypsum requirement $+\frac{1}{3} \mathrm{GR}$ as sulfur (A2), Gypsum requirement $+\frac{1}{3} \mathrm{GR}$ gypsum (A3). (Usually a third of the quantity is added to compensate for the difference between the reaction conditions in the laboratory) Sub- sub plots were two organic amendments. i.e. rice straw (01) and fine sawdust (02). 
Therefore, of each the experiment units were 36 plots, where the area of each plot was $10.5 \mathrm{~m}^{2}(3 \times 3.5 \mathrm{~m})$. Some soil physical and chemical properties of studied soil depth of $0-30 \mathrm{~cm}$ before planting were determined according to the methods described by (Cottenie et al. 1982) and (Page et al. 1982) and presented in Table (1).

Sulfur and gypsum were added at a rates of $400 \mathrm{Kg} \mathrm{S}$ / fed, while fine sawdust and rice straw were added at the rate of $2.5 \mathrm{~g} \mathrm{O} \mathrm{C} \mathrm{/} \mathrm{kg} \mathrm{soil,} \mathrm{so} \mathrm{amendments} \mathrm{were}$ applied separately; Sulfur was obtained from company for agricultural development, Cairo Governorate, also the gypsum was obtained from company for Fertilizers and Chemicals, Qalyoubia Governorate. The agricultural grade gypsum was powder with $90 \%$ purity. Fine sawdust and rice straw was obtained from farms in the same area.

The amendments applications were carried out before planting by 20 days and mixed with the surface soil $(0-15 \mathrm{~cm})$. by a plow before planting and plowing methods (conventional tillage or deep tillage) were done. The amendments analyses according to (Singh and Bhushan 1980). The obtained data are recorded in Table (2) Gypsum requirements were determined according to (FAO and IIASA 2000). These amounts are sufficient to reduce the ESP to $10 \%$ for the soil matrix in the surface layer according the following equation:

$\mathrm{Gr}=\left(\mathrm{ESP}_{\mathrm{i}}-\mathrm{ESP}_{\mathrm{F}}\right) / 100 \times \mathrm{CEC} \times 1.72$

Where Gr: gypsum requirement

$\left(\mathrm{Mg} \mathrm{fed}^{-1}\right), \mathrm{ESP}_{\mathrm{i}}$ : initial soil ESP, ESP The required soil ESP (10\%) and CEC: cation exchange capacity (cmolc $\mathrm{kg}^{-1}$ ).

Wheat grains variety (Triticum aestivum) Sakha 93) were sown at 22 October winter of 2016/2017 in first season, 2017/2018 second season, respectively Grain were obtained from Crop Research Institute, Agriculture Research Center, Giza, Egypt. Surface irrigation was adapted in this study. ElSalam Canal (Nile water mixed with agricultural drainage water 1:1) was irrigation water resource in the studied area which have the characteristics presented in Table (3). These analyzes water carried according of the methods described by Page et al. (1982).

Table 1. Some physical and chemical properties of the studied soil before cultivation

\begin{tabular}{|c|c|c|c|}
\hline Physical properties & Value & Chemical properties & Value \\
\hline Sand $\quad(\%)$ & 12.30 & Organic matter ( \%) & 0.53 \\
\hline Silt & 23.20 & $\mathrm{CaCO}_{3}(\%)$ & 6.66 \\
\hline Clay & 64.50 & $\mathrm{pH}(1: 2.5)$ & 8.65 \\
\hline Texture class & Clay & EC $\left(d S ~ m^{-1}\right)$ & 7.90 \\
\hline Bulk density kg.m ${ }^{-3}$ & 1.35 & SAR (\%) & 17.77 \\
\hline Penetration resistance $\left(\mathrm{kg} \mathrm{cm}^{-1}\right)$ & 54.30 & ESP $(\%)$ & 20.25 \\
\hline Total Porosity (\%) & 47.40 & CEC $\left(\mathrm{cmolc} \mathrm{kg}^{-1}\right)$ & 35.92 \\
\hline Hydraulic conductivity $\left(\mathrm{cm} \mathrm{h}^{-1}\right)$ & 0.45 & \multirow{2}{*}{ Gypsum requirement $\left(\mathrm{Mg} \mathrm{fed}^{-1}\right)$} & \multirow{2}{*}{6.33} \\
\hline Field capacity (\%) & 41.30 & & \\
\hline
\end{tabular}


Amelioration of salt affected soils and its productivity using soil amendments ....

Table 2. Content of important components of the amendments used in the experimental work.

\begin{tabular}{|c|c|c|c|c|}
\hline Property & $\begin{array}{c}\text { Fine } \\
\text { sawdust } \\
\text { S D }\end{array}$ & $\begin{array}{l}\text { Rice straw } \\
\text { R. S }\end{array}$ & $\begin{array}{c}\text { Gypsum } \\
\mathrm{CaSO}_{4} \cdot 2 \mathrm{H}_{2} \mathrm{O}\end{array}$ & $\begin{array}{c}\text { Elemental } \\
\text { sulfur } \mathbf{S}\end{array}$ \\
\hline Dose & \multicolumn{2}{|c|}{$2.50 \mathrm{~g} \mathrm{O.C.} \mathrm{/} \mathrm{kg} \mathrm{soil}$} & \multicolumn{2}{|c|}{$400 \mathrm{Kg} \mathrm{S} / \mathrm{fed}$} \\
\hline 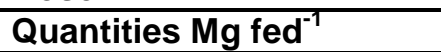 & 3.21 & 4.90 & 2.15 & 0.40 \\
\hline$E C d S ~ m^{-1} 1: 5$ & 0.20 & 1.26 & 3.84 & - \\
\hline Organic carbon $\mathbf{g} / \mathbf{K g}$ & 78.00 & 51.00 & - & - \\
\hline Total nitrogen $\%$ & 0.17 & 0.58 & - & - \\
\hline C:N ratio & 229 & 88 & - & - \\
\hline Total phosphorus \% & 0.21 & 0.10 & - & - \\
\hline Total potassium \% & 0.50 & 1.38 & - & - \\
\hline Bulk density kg.m ${ }^{-3}$ & 204.0 & 120.0 & - & - \\
\hline Moisture \% & 4.27 & 15.00 & - & - \\
\hline $\mathrm{CaSO}_{4}$ & - & - & 89 & 0.004 \\
\hline $\mathrm{SO}_{4} \%$ & - & - & $49.70 \%$ & \\
\hline S\% & - & - & $16.60 \%$ & 95 \\
\hline $\mathrm{Ca} \%$ & - & - & $20.70 \%$ & - \\
\hline Granules less than $2 \mathrm{~mm}$ & - & - & $90 \%$ & $100 \%$ \\
\hline
\end{tabular}

Table (3): Chemical analysis of irrigation water.

\begin{tabular}{|c|c|c|c|c|c|c|c|c|c|c|c|}
\hline \multirow{2}{*}{ Sample } & \multirow{2}{*}{ PH } & \multirow{2}{*}{$\begin{array}{c}E C \\
\mathrm{dS} \mathrm{m}^{-1}\end{array}$} & \multicolumn{4}{|c|}{ Cations (mmol L $\left.{ }^{-1}\right)$} & \multicolumn{4}{|c|}{ Anions $\left(\mathrm{mmol} \mathrm{L}^{-1}\right)$} & \multirow{2}{*}{ SAR } \\
\hline & & & $\mathrm{Ca}^{2+}$ & $\mathbf{M g}^{2+}$ & $\mathrm{Na}^{+}$ & $\mathrm{K}^{+}$ & $\mathrm{CO}_{3}{ }^{-2}$ & $\mathrm{HCO}_{3}^{-}$ & $\mathrm{Cl}^{-}$ & $\mathrm{SO}_{4}{ }^{-2}$ & \\
\hline \begin{tabular}{|l|} 
first \\
season
\end{tabular} & 7.81 & 1.81 & 2.27 & 4.2 & 11.96 & 0.38 & 0 & 1.13 & 10.86 & 6.82 & 6.65 \\
\hline $\begin{array}{l}\text { Second } \\
\text { season }\end{array}$ & 7.78 & 1.89 & 2.27 & 4.28 & 11.96 & 0.28 & 0 & 1.21 & 10.86 & 6.82 & 6.61 \\
\hline
\end{tabular}

The mineral fertilizers add at the recommended doses according to the Egyptian Ministry of Agriculture recommendation. Calcium super phosphate $\left(15.5 \% \mathrm{P}_{2} \mathrm{O}_{5}\right)$ was added at $200 \mathrm{~kg} / \mathrm{fed}$. during soil preparation. Nitrogen was added at rate of $100 \mathrm{Kg} \mathrm{N}$ fed $^{-1}$ in the form of ammonium nitrate $(33.5 \% \mathrm{~N})$ and potassium was added at rate of $70 \mathrm{KgK}^{20} \mathrm{fed}^{-1}$ in the form of potassium sulphate $\left(48 \% \mathrm{~K}_{2} \mathrm{O}\right)$ these quantities were applied in 3 equal doses after 21,45 and 60 day of planting. Wheat crop was harvest at 20 May 2017 and 22 May 2018.

After plant harvesting, undisturbed and disturbed soil samples were collected from each experimental plot at depths of $0-30 \mathrm{~cm}$ in the two seasons. Each disturbed soil samples were airdried and crushed to pass through $2 \mathrm{~mm}$. Some physical, chemical properties were determined according to (Cottenie et al. 1982) and (Page et al. 1982). Sodium adsorption ratio (SAR) carried out according to (Abd El-Fattah 2012). Exchangeable sodium percentage (ESP) was calculated according to the equation of (Rashidi and Seilsepours 2008): ESP = $1.95+1.03$ SAR .

Cation exchangeable capacity (CEC) and Gypsum \% were determined according to (Page et al., 1982). Yield parameters: Harvest index (H.I. \%): was H.I. = grain yield/biological yield $\times 100$ according to (Clipson et al. 1994). 


\section{Statistical analysis:}

Data were statistically analyzed using analysis of variance for split- split plot design according to Snedecor and Cochran (1982).

\section{RESULTS AND DISCUSSION}

A- Effect of different treatments on some soil physical properties after two seasons of study

\section{1- Soil bulk density (BD):}

Data in Table (4) indicate that, the values of soil bulk density trended with different treatments were relatively low and the maximum decrease exists in case of the treatment of (O2 A2) with T2 compared to other treatments. This result may be due to the organic fraction is much lighter in weight than the mineral fraction in soils. These results are confirmed with the results of (Brown and Cottone 2011), who observed that organic amendments application influences soil structure in a beneficial way by lowering soil density as a result for the admixture of low-density organic matter into the mineral soil fraction.

Accordingly, the increase in the organic fraction decreases the total weight and bulk density of the soil. Soil bulk density was varied significantly due to adding treatments and tillage methods. Similar results were obtained by (Alam et al. 2014), who found a significance variance in bulk density due to different tillage methods. They added that the improved physical and chemical properties were recorded in the conservational tillage practices. Bulk and particle densities were decreased due to tillage practices and may be attributed to the effects of tillage systems on breaking soil clods and bigger granular into smaller crumbs as well as breaking and cracking the compacted layers (Antar et al. 2008). which enhanced the formation of large soil aggregates. This could be due to the dominance of soluble $\mathrm{Ca}^{+2}$ on the exchange complex led to reduce in soil bulk density (Karen et al. 2019). (Zayed et al. 2017). revealed that applied elemental sulfur at a rate of $600 \mathrm{~kg} \mathrm{~S} \mathrm{ha}^{-1}$ under saline soil conditions at El-Sirw Agricultural Research Station caused in a significant decrease in values of soil bulk density compared with un amendments treatments after harvested wheat in both the two growing seasons. With the change of management type from conventional tillage to deep tillage (Karen et al. 2019).

\section{2- Penetration resistance (PR)}

Data presented in Table (4) show that using of different forms of amendment treatments reduced the penetration resistance values. Organic amendment have a great effective in reducing the Penetration resistance and recorded the highest of reduction compared with chemical amendments case of interaction on the highest values with decreased were found when application of fine sawdust + gypsum +sub sling plow, in lath season values.

This could be attributed to the decomposition amendments and increasing both soluble and exchangeable calcium which enhanced the soil aggregates processes which increase both of total porosity and drainable pores, subsequently soil penetrability resistance decreases. These results were similar to that reported by (Mansour, 2012) and (Abd El-Hamid et al. 2011). Results of the statistical analysis indicated that there are significant differences among forms of the used amendments, tillage system. 
Amelioration of salt affected soils and its productivity using soil amendments ....

Table (4): Some soil physical properties after two seasons of study affected by different treatments after two experiment seasons.

\begin{tabular}{|c|c|c|c|c|c|c|c|c|c|c|c|c|c|}
\hline \multirow{3}{*}{$\begin{array}{l}\text { Organic } \\
\text { Amendment } \\
(0)\end{array}$} & \multirow{3}{*}{$\begin{array}{l}\text { Chemical } \\
\text { Amendment } \\
\text { (A) }\end{array}$} & \multirow{2}{*}{\multicolumn{3}{|c|}{$\begin{array}{c}\text { B.D } \\
\left(\mathrm{Mg} / \mathrm{cm}^{3}\right)\end{array}$}} & \multirow{2}{*}{\multicolumn{3}{|c|}{$\begin{array}{c}\text { P.R. } \\
\left(\mathrm{kg} \mathrm{cm}^{-1}\right)\end{array}$}} & \multirow{2}{*}{\multicolumn{3}{|c|}{$\begin{array}{l}\text { T.P. } \\
\text { (\%) }\end{array}$}} & \multirow{2}{*}{\multicolumn{3}{|c|}{$\frac{\text { H.C. }}{\left(\mathrm{cmh}^{-1}\right)}$}} \\
\hline & & & & & & & & & & & & & \\
\hline & & $T_{1}$ & $T_{2}$ & Mean & $T_{1}$ & $T_{2}$ & mean & $T_{1}$ & $T_{2}$ & Mean & $T_{1}$ & $T_{2}$ & Mean \\
\hline \multicolumn{14}{|c|}{ First season } \\
\hline & Control A1 & 1.31 & 1.29 & 1.30 & 50.30 & 49.10 & 49.70 & 50.30 & 51.10 & 50.70 & 0.48 & 0.49 & 0.49 \\
\hline Rice & Sulfur & 1.29 & 1.26 & 1.28 & 46.10 & 44.30 & 45.20 & 52.80 & 53.40 & 53.10 & 0.48 & 0.53 & 0.51 \\
\hline straw & Gypsum A3 & 1.27 & 1.25 & 1.26 & 45.30 & 42.90 & 44.10 & 53.20 & 55.50 & 54.35 & 0.55 & 0.58 & 0.57 \\
\hline \multirow[t]{2}{*}{01} & mean & 1.29 & 1.27 & 1.28 & 47.23 & 45.43 & 46.33 & 52.10 & 53.33 & 52.72 & 0.50 & 0.53 & 0.52 \\
\hline & $\begin{array}{ll}\text { Control } & \text { A1 }\end{array}$ & 1.29 & 1.28 & 1.29 & 48.30 & 47.10 & 47.70 & 53.30 & 55.10 & 54.20 & 0.55 & 0.60 & 0.58 \\
\hline Fine & Sulfur & 1.26 & 1.24 & 1.25 & 44.10 & 43.30 & 43.70 & 55.18 & 55.40 & 55.29 & 0.58 & 0.63 & 0.61 \\
\hline sawdust & Gypsum A3 & 1.25 & 1.22 & 1.24 & 43.30 & 41.90 & 42.60 & 55.62 & 57.00 & 56.31 & 0.59 & 0.65 & 0.62 \\
\hline 02 & mean & 1.27 & 1.25 & 1.26 & 45.23 & 44.10 & 44.67 & 54.70 & 55.83 & 55.27 & 0.57 & 0.63 & 0.60 \\
\hline \multicolumn{14}{|l|}{ L. S.D at .05} \\
\hline$A(T)$ & & 0.02 & & & 0.02 & & & 0.02 & & & 0.01 & & \\
\hline B (A) & & 0.01 & & & 0.02 & & & 0.04 & & & 0.03 & & \\
\hline C (0) & & 0.01 & & & 0.05 & & & 0.01 & & & 0.01 & & \\
\hline$A^{*} B$ & & 0.01 & & & 0.04 & & & 0.01 & & & 0.02 & & \\
\hline$A{ }^{*} C$ & & 0.02 & & & 0.05 & & & 0.02 & & & 0.02 & & \\
\hline$B^{*} C$ & & 0.01 & & & 0.01 & & & 0.01 & & & 0.01 & & \\
\hline$A^{*} B^{*} C$ & & 0.04 & & & 0.04 & & & 0.04 & & & 0.13 & & \\
\hline
\end{tabular}

Second season

\begin{tabular}{lllllllllllllll}
\hline & Control & A1 & 1.28 & 1.26 & 1.27 & 48.30 & 46.10 & 47.20 & 52.10 & 52.20 & 52.15 & 0.55 & 0.65 & 0.60 \\
Rice & Sulfur & A2 & 1.27 & 1.24 & 1.26 & 44.10 & 43.30 & 43.70 & 53.40 & 54.40 & 53.90 & 0.58 & 0.65 & 0.62 \\
straw & Gypsum & A3 & 1.26 & 1.23 & 1.25 & 43.30 & 42.90 & 43.10 & 55.50 & 56.15 & 55.83 & 0.65 & 0.76 & 0.71 \\
O1 & mean & & 1.27 & 1.24 & 1.26 & 45.23 & 44.10 & 44.67 & 53.67 & 54.25 & 53.96 & 0.59 & 0.69 & 0.64 \\
\hline & Control & A1 & 1.27 & 1.25 & 1.26 & 47.30 & 47.10 & 47.20 & 55.10 & 56.91 & 56.01 & 0.76 & 0.80 & 0.78 \\
Fine & Sulfur & A2 & 1.26 & 1.23 & 1.25 & 43.10 & 42.30 & 42.70 & 55.40 & 55.94 & 55.67 & 0.78 & 0.86 & 0.82 \\
sawdust & Gypsum & A3 & 1.24 & 1.21 & 1.23 & 42.30 & 41.90 & 42.10 & 57.00 & 58.90 & 57.95 & 0.79 & 0.87 & 0.83 \\
O2 & mean & & 1.26 & 1.23 & 1.24 & 44.23 & 43.77 & 44.00 & 55.83 & 57.25 & 56.54 & 0.78 & 0.84 & 0.81 \\
\hline
\end{tabular}

L. S.D at 0.05

$\begin{array}{lllll}A(T) & 0.01 & 0.01 & 0.02 & 0.10 \\ B(A) & 0.12 & 0.10 & 0.04 & 0.12 \\ C(O) & 0.01 & 0.11 & 0.03 & 0.10 \\ A^{*} B & 0.10 & 0.01 & 0.12 & 0.02 \\ A^{*} C & 0.11 & 0.02 & 0.10 & 0.05 \\ B^{*} C & 0.10 & 0.01 & 0.11 & 0.02 \\ A^{*} B^{*} C & 0.12 & 0.03 & 0.10 & 0.10\end{array}$

$T_{1}$ conventional tillage, $T 2$ deep tillage

\section{3- Total porosity (TP)}

Total porosity is a special formula which explains the relationship between both the soil real and bulk densities. On the other hand, it is an index of the relative volume of pores in soil, results 
after harvesting presented in Table (4) show that, the mean values of total soil porosity significantly increased due to the effect of the application amendment and tillage system compared with the control. in both seasons these results may be attributed to the effects of T2 or T1 on breaking soil clods and bigger granular into smaller crumbs as well as breaking and cracking the compacted layers (Antar et al. 2008). which enhanced the formation of large soil aggregates and (Hussain et al. 2001) stated that physical properties like total soil porosity was significantly improved when organic amendments were applied in with chemical amendments, resulting in enhanced wheat yields in sodic soil. Total soil porosity was varied significantly due to treatments and tillage methods and it was higher in deep tillage than in conservational tillage. These results are confirmed with the results of (Hossein et al. 2017).

\section{Hydraulic conductivity}

Data presented in Table (4) reveals that the average values of hydraulic conductivity (HC) content after harvesting of wheat in the two seasons, influenced by application of the different under two tillage systems significantly increased due to the effect of tillage system. In this respect, the effect of chemical or organic amendments increased the values of hydraulic conductivity. Also, data show that the applied different organic amendments significantly differed in their effect on the value with the superiority organic over the other mineral amendments. In results of hydraulic conductivity after harvesting of either wheat, as influenced by application of the different amendments treatments, combined with tillage system, the deep tillage was more effective compared with conventional tillage. The efficiency of the studied amendments on increasing the values of hydraulic conductivity could be attributed to the effect of such treatments increased the macro pores and decreased the micro pores (Reda 2006). The addition of fine sawdust increases significantly the falling-head permeability, which is a sign improvement of soil hydro-physical properties (Abd El-Halim and ElBaroudy, 2014).

\section{B- Effect of different treatments on some soil chemical properties after two seasons of study. \\ 1- Electrical conductivity ( ECe )}

Data presented in Table (5) showed that the effect of tillage systems and different amendments chemical or organic on soil electric conductivity (Ec) after both harvest of two seasons were decreased compared with initial EC soil and different significant. This reduction of soil salinity $(\mathrm{Ec})$ was attributed to the high leaching of solute in the treated soil. Because presence of large pores that enhance the solute convective process. The lowest ECe values were observed in the deep tillage (6.69) and (5.44), in the first and second season, respectively.

These results it could be the decrease of soil salinity (EC) reflect increasing deep tillage system. These results agree by (Abd El-Rahman et al. 2012) who indicated that under the condition of deep tillage, the ability is desalination and improving saline soil. Similar results were obtained by (Rasouli et al. 2014) who observed also a slight variance in EC values between different tillage methods. application of such amendments significantly decreased soil EC values decreasing EC In addition, The reduction of soil salinity with amendments which allows continues supply of $\mathrm{Ca}^{2+}$, this cation led to replace the exchangeable $\mathrm{Na}^{+}$from soil matrix and to from new stable aggregates. These process decreased EC and 
encourage the water to flow down and leach the salt out (Aggag and Mahmoud 2006) and Zamil (2012) reveled that leaching is the only effective way to decrease the excessive salts from the root zone. Moreover, these reactions promote water infiltration, the majority of these soluble salts leached with the drainage water.

\section{Soil pH}

In general, results in Table (5) reveal that, the $\mathrm{pH}$ values of the investigated soil as affected by the tillage systems individually are combined the case of addition of soil amendments the data show that this addition with soil amendments in both season. In the values of soil $\mathrm{pH}$ were decreased due to the effect of amendments. When the different amendment were applied to soil. The (02) treatment was being more effective in decreasing soil $\mathrm{pH}$, (8.47) individually are combined with (8.44) (A2) and (T2) as compared with other treatments. These results may be due to the application of of organic materials probably enhanced the partial pressure of $\mathrm{CO}_{2}$ because of increases of the microbial activity. This possibly caused by the formation of organic and inorganic acids, which lead to decreasing $\mathrm{pH}$ in organic treated soils (Wong et al. 2009). Furthermore, solubilization of minerals such as $\mathrm{Ca}$, the decrease of $\mathrm{pH}$ in saltaffected soils by exchanging with $\mathrm{Na}^{+}$ from cation exchange complex (Chaganti and Crohn 2015). Reductions in pH with application of organic amendments to salt-affected soils were also stated by other researchers (Chaganti et al. 2015) and (Helmy and Shaban 2013). (Joachim and Hubert 2010) indicated that the application of sulfur and gypsum to saline-sodic and sodic soils led to reducing of $\mathrm{pH}$. The decrease in $\mathrm{pH}$ by sulfur and gypsum could be because of $\mathrm{Na}^{+}$replacement with $\mathrm{Ca}$., reported by (Abd El-Rahman et al. (2012), who observed a decrease in soil $\mathrm{pH}$ after using compost and gypsum. The positive effect of compost on improving soil chemical properties could be due to release of $\mathrm{CO}_{2}$ during the degradation process and thus decreased the precipitation of $\mathrm{Ca}^{2+}$ (Elgezairi, 2016). This slight decrease in $\mathrm{pH}$ could be attributed to the buffering capacity of the investigated soil. Buffering capacity of a soil is defined as a soil's ability to resist change in $\mathrm{pH}$ or maintain a constant $\mathrm{pH}$ level when acids or bases are added to that soil (Glinski et al. 2011).

\section{Exchangeable sodium percentage (ESP)}

Data presented in Table (5) show that, the using resources different forms of soil amendments organic or chemical individually reduced the ESP values, also in the presence of tillage after wheat harvest, the reduced were more ehective. on the other hand, the values of soil ESP were more a significantly decreased as a result of the addition of chemical and organic amendments to the soil. The application of studied chemical amendments had a significant positive effect in decreasing the soil ESP values, and caused the highly lowered soil ESP values. It was moticu that (02) amendment was most effective in reducing the ESP values than rice straw in both seasons under deep tillage system. This may be due to the release of organic acids and $\mathrm{CO}_{2}$ ions during the decomposition process of organic materials i.e., Fine sawdust and rice straw and thus decreased precipitation of $\mathrm{Ca}^{2+}$ and $\mathrm{CO}_{3}$ ions which should lead to decrease ESP. This effect is more pronounced in the surface layer. Surface applied water would pass through the surface applied amendment and infiltrate the top layers allowing exchange process between $\mathrm{Ca}^{2+}$ and $\mathrm{Na}^{+}$(El-Sharawy et al. 2003). 
Table 5. Soil pH, ECe, ESP and O.M as affected by different treatments after two experimental seasons.

\begin{tabular}{|c|c|c|c|c|c|c|c|c|c|c|c|c|c|}
\hline \multirow{3}{*}{$\begin{array}{c}\text { Organic } \\
\text { Amendment } \\
\text { (0) }\end{array}$} & Chemical & \multicolumn{3}{|c|}{$\mathrm{pH}$} & \multicolumn{3}{|c|}{ EC } & \multicolumn{3}{|c|}{ ESP } & \multicolumn{3}{|c|}{ O.M. } \\
\hline & Amendment & \multicolumn{3}{|c|}{$(1: 2.5)$} & \multicolumn{3}{|c|}{$(\mathrm{dSm}-1)$} & \multicolumn{3}{|c|}{ (\%) } & \multicolumn{3}{|c|}{ (\%) } \\
\hline & (A) & $T_{1}$ & $T_{2}$ & mean & $T_{1}$ & $T_{2}$ & mean & $T_{1}$ & $T_{2}$ & Mean & $T_{1}$ & $T_{2}$ & Mean \\
\hline \multicolumn{14}{|c|}{ First season } \\
\hline & Control A1 & 8.45 & 8.37 & 8.41 & 7.60 & 7.46 & 7.53 & 17.77 & 17.00 & 17.39 & 0.53 & 0.52 & 0.53 \\
\hline Rice & Sulfur & 8.42 & 8.35 & 8.39 & 7.20 & 7.15 & 7.18 & 15.50 & 15.40 & 15.45 & 0.54 & 0.53 & 0.54 \\
\hline straw & Gypsum A3 & 8.40 & 8.32 & 8.36 & 6.66 & 6.45 & 6.56 & 14.40 & 13.50 & 13.95 & 0.55 & 0.57 & 0.56 \\
\hline \multirow[t]{2}{*}{01} & mean & 8.42 & 8.35 & 8.39 & 7.15 & 7.02 & 7.09 & 15.89 & 15.30 & 15.60 & 0.54 & 0.54 & 0.54 \\
\hline & Control A1 & 8.38 & 8.32 & 8.35 & 6.78 & 6.45 & 6.62 & 16.50 & 15.20 & 15.85 & 0.54 & 0.53 & 0.54 \\
\hline Fine & Sulfur & 8.36 & 8.31 & 8.34 & 6.70 & 6.37 & 6.54 & 15.40 & 15.10 & 15.25 & 0.55 & 0.54 & 0.55 \\
\hline sawdust & Gypsum A3 & 8.33 & 8.29 & 8.31 & 6.44 & 6.26 & 6.35 & 14.30 & 13.42 & 13.86 & 0.55 & 0.56 & 0.56 \\
\hline 02 & mean & 8.36 & 8.31 & 8.33 & 6.64 & 6.36 & 6.50 & 15.40 & 14.57 & 14.99 & 0.55 & 0.54 & 0.55 \\
\hline \multicolumn{14}{|l|}{ L. S.D at .05} \\
\hline$A(T)$ & & 0.03 & & & 0.02 & & & 0.02 & & & 0.01 & & \\
\hline B (A) & & 0.02 & & & 0.02 & & & 0.04 & & & 0.01 & & \\
\hline C (0) & & 0.01 & & & 0.05 & & & 0.01 & & & 0.01 & & \\
\hline$A^{\star} B$ & & 0.01 & & & 0.04 & & & 0.01 & & & 0.01 & & \\
\hline$A * C$ & & 0.02 & & & 0.05 & & & 0.02 & & & 0.02 & & \\
\hline $\mathrm{B}^{\star} \mathrm{C}$ & & 0.01 & & & 0.01 & & & 0.01 & & & 0.01 & & \\
\hline$A^{*} B^{*} C$ & & 0.04 & & & 0.04 & & & 0.04 & & & 0.10 & & \\
\hline \multicolumn{14}{|c|}{ Second season } \\
\hline & Control A1 & 8.32 & 8.30 & 8.31 & 5.69 & 5.62 & 5.66 & 17.07 & 16.50 & 16.79 & 0.51 & 0.50 & 0.51 \\
\hline Rice & Sulfur A2 & 8.27 & 8.27 & 8.27 & 5.57 & 5.51 & 5.54 & 15.16 & 14.70 & 14.93 & 0.52 & 0.51 & 0.52 \\
\hline straw & Gypsum A3 & 8.26 & 8.25 & 8.26 & 5.46 & 5.53 & 5.41 & 14.14 & 13.35 & 13.75 & 0.54 & 0.53 & 0.54 \\
\hline \multirow[t]{2}{*}{01} & mean & 8.28 & 8.27 & 8.28 & 5.57 & 5.55 & 5.54 & 15.46 & 14.85 & 15.16 & 0.52 & 0.51 & 0.52 \\
\hline & Control A1 & 8.30 & 8.28 & 8.29 & 5.57 & 5.49 & 5.53 & 15.46 & 14.85 & 15.15 & 0.52 & 0.51 & 0.52 \\
\hline Fine & Sulfur & 8.26 & 8.26 & 8.26 & 5.68 & 5.47 & 5.58 & 16.25 & 15.12 & 15.69 & 0.54 & 0.53 & 0.54 \\
\hline sawdust & Gypsum A3 & 8.25 & 8.24 & 8.25 & 5.57 & 5.35 & 5.46 & 15.34 & 15.00 & 15.17 & 0.55 & 0.54 & 0.55 \\
\hline 02 & mean & 8.27 & 8.26 & 8.27 & 5.61 & 5.44 & 5.52 & 15.68 & 14.99 & 15.34 & 0.54 & 0.53 & 0.54 \\
\hline
\end{tabular}

L. S.D at .05

$\begin{array}{lllll}A(T) & 0.01 & 0.01 & 0.02 & 0.10 \\ B(A) & 0.01 & 0.10 & 0.04 & 0.10 \\ C(O) & 0.01 & 0.11 & 0.01 & 0.10 \\ A^{*} B & 0.10 & 0.01 & 0.10 & 0.02 \\ A^{*} C & 0.10 & 0.02 & 0.10 & 0.02 \\ B^{*} C & 0.10 & 0.01 & 0.10 & 0.02 \\ A^{*} B^{*} C & 0.10 & 0.01 & 0.10 & 0.10\end{array}$

$T_{1}$ conventional tillage, $T 2$ deep tillage 


\section{4 - Organic matter (OM)}

Organic matter is regarded as the ultimate source of organic amendments and microbial activity in the soil. It is the deciding factor in soil structure, water holding capacity, infiltration rate, aeration and porosity of the soil. Data presented in Table (5) showed that all treatments of added soil amendments increased the content O.M (\%) of in soil under different tillage methods, however deep tillage produced slightly higher values of $O . M$ than conservational tillage. These results are in agreement with those of (Muhammad and Khattak 2009) who found that the application of compost resulted in overall increase of the soil organic matter level.

Generally, application of organic materials (O) chemical (A) were amendments more effective under deep tillage (T2) treatment, compared with the control and other treatments in both seasons. This could be due to the rabid oxidation and decomposition of soil organic matter with time (EI-Sharawy et al. 2003).

C- Effect of different tillage system and soil soil amendments on grains, straw, total yield and harvest index of wheat (Mg fed. ${ }^{-1}$ ),

\section{Wheat grains, straw and total} yield:

The effect of soil amendments addition on wheat yield (grains, straw and total yield) are shown in Table (6). It can be notice that all of the used soil amendments treatments significantly increased the grains, straw and total yields of wheat in both season. As addition of soil amendments resulted in highest increasing in grains, straw and yields values of two growing seasons in under two tillage. These results are in agreement with those obtained by (Ahmed et al. 2016), who observed a high increase in wheat straw, grain and total yields due to using sulphur and gypsum applications. Also, (Abd El-Rahman et al. 2012) found that an increase in wheat grain after using rice straw in salt affected soil. Also, it is clear that grains and straw yields of wheat in subsurface tillage were slightly higher than those in surface tillage. This may be attributed to that using of subsurface tillage decreased $\mathrm{pH}$ and EC and improved soil physical properties which led to increase availability of nutrients and increase wheat yield. Data agree with the results reported by (Hossein et al. 2017).

\section{2- Harvest index}

Data presented in Table (6) showed that the effect of tillage systems, soil amendments chemical and organic enhanced harvest index in both seasons. Results revealed that tillage systems and all amendments resulted in a significant increas effect on grain yield/fed. in both seasons. While, tillage systems, chemical amendments and organic amendments showed insignificant effect harvest index in both seasons. In the first season was obtained. (Wasaya et al. 2011).

\section{CONCLUSION}

The economics of salt-affected soils reclamation require low-cost method for successful implementation. Tillage system, chemical and organic amendments. Thus, they are amendments that are more economical. All amendments examined in the present study were efficient at remediating of salt-affected soils properties and improving yield. The commonly used amendment sulfur was less effective than gypsum on the ether hand organic amendments in ameliorating sodicity and improves salt-affected soils. Hence, use of such organic wastes as (fine sawdust and rice straw ) in salt-affected soils reclamation provides an environmentally. 
Table 6. Grains, straw, total yields and harvest index of wheat as affected by different treatments under different tillage.

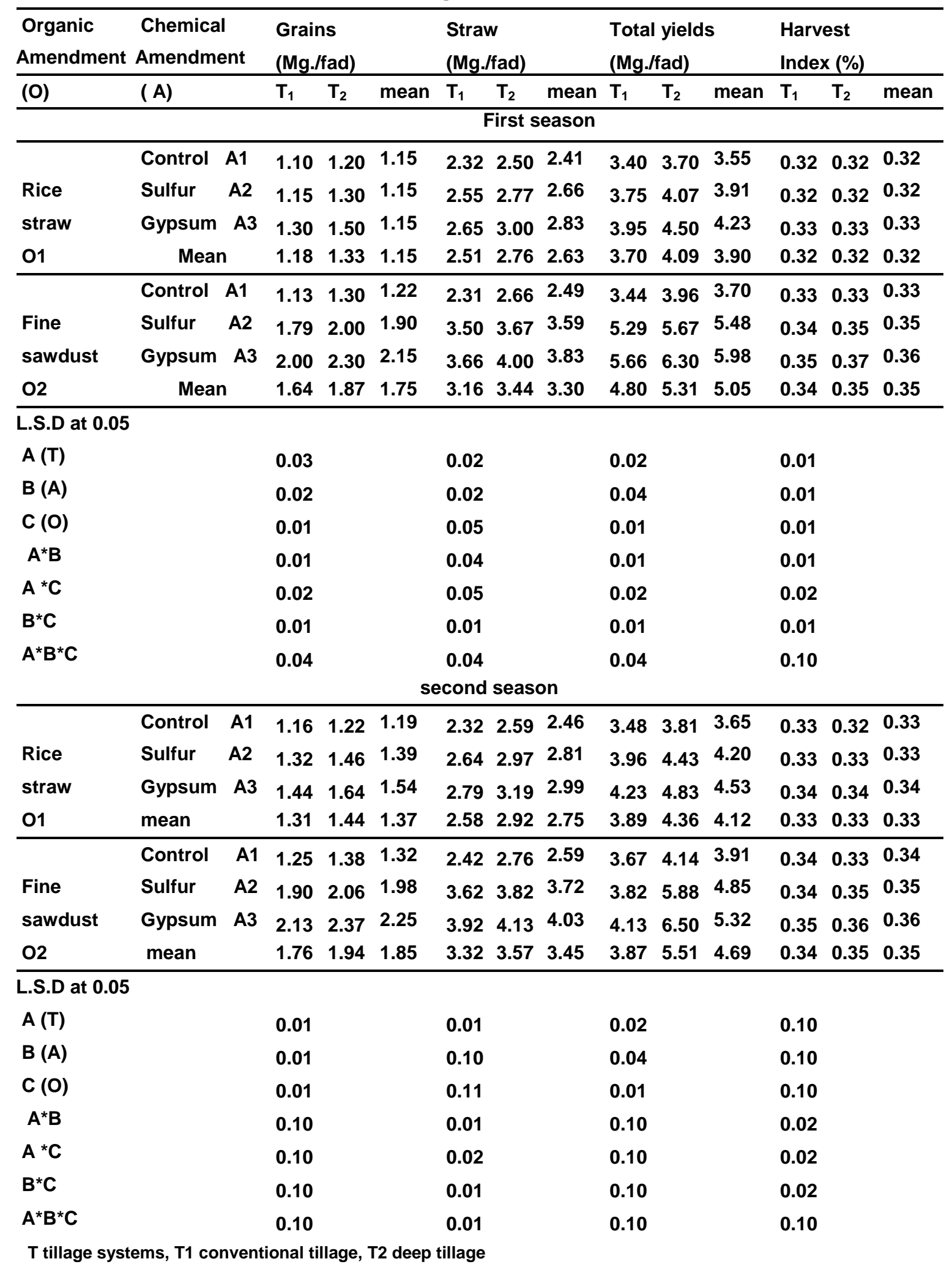




\section{REFERENCES}

Abd El-Fattah, M.K. (2012). Role of gypsum and compost in reclaiming saline-sodic soils. IOSR J. Agric. and Veterinary Sci., 13: 30-38.

Abd El-Halim, A. A. and A.A. El- Baroudy (2014). Influence addition of Fine sawdust on the Physical Properties of Expansive Soil in the Middle Nile Delta, Egypt Journal of Soil Science and Plant Nutrition. 14 (2): 483-490.

Abd El-Hamid, A.R., S.F. Mansour, T.A. El- Maghraby and M.A.A. Bakry (2011). Competency of some soil amendments used for improvement of extreme salinity of Sahl El-Tina Soil North-Sinai. J. Soil Sci. and Agric. Eng., Mansoura Univ., 26: 649-667.

Abd El-Rahman, Sh. H., M. A.M. Mostafa, T. A. Taha, M. A. O. Elsharawy and M. A. Eid (2012). Effect of different amendments on soil chemical characteristics, grain yield and elemental content of wheat plants grown on salt- affected soil irrigated with low quality water. Annals of Agricultural Science 57 (2): 175- 182.

Aggag, A.M. and E.K. Mahmoud (2006). Influnce of alum sludge and gypsum application to improve soil quality and yield wheat grown on salt-affected soils. J. Agric. Res. Tanta Univ., 4: 3237.

Ahmed, R. Azza (2018). An attempt for ameliorating the calcareous soil behavior and its productivity. Nature and Science, $16(8):$ 16:25.

Ahmed, K., G. Qadir, A.R. Jami, A.I. Saqib, M.Q. Nawaz, M.A. Kamal and E. Haq (2016). Strategies for Soil Amelioration Using Sulphur in Salt Affected Soils. Cercetări Agronomice în Moldova, Vol. XLIX, No. 3 (167): 516.

Aiad, M.A.F., M.A. Abd El-Aziz, B.A.A. Zamil and A.S. Antar (2012). Combating of soil deterioration at
North Delta. Egypt. J. Agric. Res. Kafrelsheikh Univ., 38 (2): 322-341.

Alam, K., M. Islam, N. Salahin and M. Hasanuzzaman (2014). Effect of Tillage Practices on Soil Properties and Crop Productivity in Wheat-Mungbean-Rice Cropping System under Subtropical Climatic Conditions, The Scientific World Journal, Volume 2014, Article ID 437283, 15 pages.

Antar, S. A., A. S. El -Henawy and Atwa, A.A.E. (2008) Improving some properties of heavy clay salt affected soil as a result of different subsurface tillage. J. Agric. Sci. Mansoura Univ., 33 (10): 7675 - 7687 .

Begum, M. and H.R. Khan. (2013). Influence of gypsum, rice-hull and different levels of saline water irrigation on water soluble cations and organic matter content in different saline soils in response to wheat. International J. Res. Applied Nat. and Social Sci. 1: 15-22.

Brown, S. and M.Cottone, (2011). Changes in Soil Properties and Carbon Content Following Compost Application: Results of On-farm Sampling. Compost Science and Utilization, Vol.

Chaganti, V.N. and D.M. Crohn (2015). Evaluating the relative contribution of physiochemical and biological factors in ameliorating a saline-salt-affected soils amendments with composts and biochar and leached with reclaimed water. Geoderma 259-260: 45-55.

Chaganti, V.N., D.M. Crohn and J. Simunek (2015). Leaching and reclamation of a biochar and compost amended saline-salt-affected soils with moderate SAR reclaimed water. Agricultural Water Management 158: 255-265.

Chen, W., Z. Hou, L. Wu, Y. Liangand and C. Wei (2010). Effects of salinity and nitrogen on cotton growth in arid 
environment. Plant Soil, 32 (6): 61 73.

Choudhary, O.P. (2017). Use of Amendments in Ameliorating Soil and Water Sodicity. In: Arora S., Singh A., Singh Y. (eds) Bioremediation of Salt Affected Soils: An Indian Perspective. Springer, Cham. pp 195-210.

Clipson, N. J. W., S. J. Edwards, J. F. Hall, C. K. Leach, F. W. Rayns and G.D. Weston (1994). Crop Productivity. Published on Behalf of: Open Univ. and Univ. Green wish (Formerly Thames Polytechnic), Avery Hill Road, Eltham, London SE92HB, 5.

Cottenie, A., M. Verloo, L. Kiekens, G. Velgh and R. Camerlynck (1982). Chemical Analysis of Plants and Soils. Laboratory of Analytical and Agrochemistry, State University, Ghent, Belgium, 63 p.

Dodd, K., C.N. Guppy, P.V. Lockwood and I.J. Rochester (2013). The effect of sodicity on cotton: does soil chemistry or soil physical condition have the greater role? Crop and Pasture Science 64: 806-815.

Elgezairi, M. Kh. (2016). Effect of organic additives on efficiency of sulphur fertilization. M.Sc. Thesis, Fac. Of Agric. Menoufia Univ. Shebin El-Kom, Egypt.

El-Sabry, W. S., M.A. Abou El-Soud, M.S.M. Abo Soliman and A. M. ElAbasiri, (1992). Effect of sandy back filled mole on some physical and chemical properties and productivity of clayey compacted soil . J. Agric. Sci., Mansoura Univ., 17 (8): 27902797.

El-Sharawy, M.A.O., M.A. Abdel-Aziz and L.K.M. Ali (2003). Effect of the application of plant residues composts on some soil properties and yield of wheat and corn plants. Egypt. J. Soil Sci., 43: 421-434.
Emad, F. Aboukila: (2019). Use of Spent Grains, Cheese Whey, Gypsum, and Compost for Reclamation of Sodic Soils and Improvement of Corn Seed Germination. Alexandria. science exchange Journal, 40 (2): 312-326.

FAO and IIASA (2000). Diagnosis and improvement of saline and alkali sols, USDA Handbook No 60, U.S. Salinity Lab. Staff (1954), Washington.

Glinski, J., J. Horabik and J. Lipiec (2011). Encyclopedia of Agrophysics. Springer, Dordrecht, Netherland, pp. 94-95.

Helmy, A.M. and Kh.A. Shaban (2013). Wheat productivity and nutrient uptake after inhibitory soil salinity adverse by some sulphur sources. Egypt. J. Soil Sci., 53(2): 281-298.

Hossein, T., G. Cayci and K.A. Rezaeieh (2017). The effects of tillage methods on soil aggregation and crop yields in a wheat-corn rotation under semi-arid conditions. Solid Earth Discuss., doi:10.5194/se-2017-13, 2017.

Hussain, N., G. Hassan, M. Arshadullah and F. Mujeeb (2001). Evaluation of amendments for the improvement of physical properties of sodic soil. Int. J. Agric. and Boil., 3(3): 319-322.

Joachim, H. J. R. and V. Hubert (2010). Effect of gypsum placement on the physical chemical properties of a saline sandy loam soil. Austr. J. of Crop Sci. 4 7: 556- 563.

Julian, Cuevas loannis N. Daliakopoulos, Fernando del Moral, Juan J. Hueso and loannis K. Tsanis (2019). A Review of Soil-Improving Cropping Systems for Soil Salinization Agronomy. 9 (295): 1-22.

Karen, Denisse Ordoñez-Morales, Martin Ca dena-Zapata, Alejandro ZermeñoGonzález and Santos Campos-Magaña (2019). Effect of Tillage Systems on Physical Properties of a Clay Loam 
Soil under Oats. Agriculture 9 (62): 113.

Lakdhar, A., M. Rabhi, T. Ghnaya, F. Montemurro, N. Jedidi and C. Abdelly (2009). Effectiveness of compost use in salt-affected soil. J. Hazard. Mater. 171 (1-3): 29-37.

Lampurlanes, J., P. Angas and C. Cantero-Martinez (2001). Root growth, soil water content and yield of barley under different tillage systems on two soils in semi-arid conditions. Field Crop Research, 69 (1): 27-40.

Li, Y., K.K. Lee, C. Smith, S. Walsh, S. Hadingham, K. Sorefan, G. Cawley and M.W. Bevan (2006). Establishing glucose- and ABA- regulated transcription networks in Arabidopsis by microarray analysis and promoter classification using a relevance vector machine. Genome Research, in press, 16 (3): 414-427.

Mahmoud, Esawy Nasser Abd EL- Kader, Paul Robin, Nouraya Akkal-Corfini and Lamyaa Abd El-Rahman (2009). Effects of Different Organic and Inorganic Fertilizers on Cucumber Yield and Some Soil Properties. World Journal of Agricultural Sciences 5 (4): 408-414.

Mansour, S.F. (2012). Comparative effect of some industrial wastes as soil conditioners on some physiochemical hydro physical soil properties and maize productivity. Minufiya J.Agric. Res. 2: 387-396.

Mc Cauley, A., C. Jones and K. OlsonRutz (2017). Soil pH and organic matter. Nutrient Management Module No. 8, Montana State Univ. Extension, $16 \mathrm{p}$.

Mohamedin, A. A. M., M. Abdel-warth, A.A. Mahmoud and A. M. El-Melegy (2005). Effect of amendments followed by saline water on properties and productivity of highly alkali soils. Egypt. J. of App.Sci., 20: 258-268.
Muhammad, D. and R.A. Khattak (2009). Growth and nutrient concentration of maize in pressmud treated salinesodic soils. Soil Environ., 28: 145-155.

Negm, A.M. (2017). The Nile Delta. Part 3: Management of Salt-Affected Soils in the Nile Delta Ed. Mohamed, N.N., The Handbook of Environmental Chemistry, Vol. 55, Springer, $537 \mathrm{p}$.

Norton, J. and C. Strom (2012). Successful restoration of severely disturbed wyoming lands: Reclamation on salt/sodium-affected soils. Univ. Wyoming Ext., bull., 1231, $12 \mathrm{p}$.

Osman, H.A., A.R. Ahmed and M.M.M. Mohamed (2016). Effects of saltaffected soil ameliorated with gypsum, compost or sulphuric acid on the reproductive parameters of root knot nematode, Meloidogyne incognita infecting tomato plants var. castle rock under green house conditions. Int. J. Pharm Tech. Res., 9 9: 66-74.

Ouda, S.A.H. and A.E. Zohry (2016). Management of Climate Induced Drought and Water Scarcity in Egypt. Unconventional Solutions. In: Springer Briefs in Environmental Science. Chapter 6: Combating Deterioration in Salt-Affected Soil in Egypt by Crop Rotations (Eds. Ouda, S.A.H., Zohry, A.El. and Khalifa, H.), Springer, Switzerland, pp. 77-96.

Page, A.L., R.H. Miller and D.R. Keeney (1982). Methods of Soil Analysis. Part2d: Chemical and microbiological Properties. 2n ed. American Society of Agronomy, Madison, Wisconsin. USA.

Rashidi, M. and M. Seilsepour (2008). Modeling of laboratory test and the soil ESP-SAR model were soil cation exchange capacity based on some soil calculated at-1.30 and $1.62 \%$ (Fig. 2). Thus, soil ESP physical and chemical properties. ARPN J. Agril. predicted by the soil ESP-SAR model 
may be $1.30 \%$ lower Biol. Sci., 3 (2): 613.

Rasouli, F., S. Afzalinia, P.A. Kiani and M. Alavimanesh (2014). Effect of different tillage on soil properties and wheat yield in saline condition of temperate region of Fars province. Agricultural Scientific Information and ocumentation Centre, Agricultural Research and Education Organization.

Reda, M.M.A. (2006). Amelioration techniques for saline sodic soils in north Nile delta and its impact on sunflower productivity. Egyp.t, J. Appl. Sci.21: 213-228.

Sharma, Bharat R. and P.S. Minhas (2005). Strategies for managing saline/alkali waters for sustainable agricultural production in South Asia. Agricultural Water Management 78 (2): 136-151.

Singh, G., P.N. Singh and L.S. Bhushan (1980). Water use and wheat yields in Northern India under different irrigation regimes. Agric. Water Management, 3: 107-114.

Snedecor, G.W. and W.G. Cochran (1982). Statistical Methods. 7th Ed., lowa State Univ. Press, Ames., lowa, USA.

Toufiq, lqbal (2018). Rice straw amendment ameliorates harmful effect of salinity and increases nitrogen availability in a saline paddy soil. Journal of the Saudi Society of Agricultural Sciences. 17(4): 445-453.
Wasaya, Allah Muhammad Tahir, Abdul Manaf1, Mukhtar Ahmed, Shuaib aleem and ljaz Ahmad (2011). Improving maize productivity through tillage and nitrogen management African Journal of Biotechnology. 10(81): 19025-19034.

Wong, V.N.L., R.C. Dalal and R.S.B. Greene (2009). Carbon dynamics of sodic and saline soils following gypsum and organic material additions: a laboratory incubation. Appl. Soil Ecol. 41: 29-40.

Worku, A. (2015). Assessment and mapping of fertility status of salt affected soils in amibara area, central rift valley of ethiopia. M.Sc. Thesis, Dept. Soil Sci., School of Nature Res. Manage. and Environ. Sci., Haramaya Univ., Haramaya, Ethiopia, 106 p.

Yan, Y., L. Jie, L. Chunmeng, Z. Shuang and L. Zhaohua (2015). Effect of organic materials on the chemical properties of saline soil in the Yello River Delta of China. Front. Earth Sci., 92: 259-267.

Zamil, B.A. (2012). Effect of mole drain spacing and filling material on some soil properties, yield of flax and kenaf and some water relations in the north middle Nile Delta. Minufiya J. Agric. Res. 37 (4) part 2 AUG.

Zayed, B.A., M.S.M. Abdel-Aal and G.A. Deweedar (2017). Response of rice yield and soil to sulfur application under water and salinity stresses. Egypt. J. Agron., 39 (3): 239-249. 
علاج الاراضى المتأثرة بالأملاح وإنتاجياتها باستخدام المصلحات ونظام الخدمة

\author{
طارق هاشم محمد عبدالعزيز دشيش \\ معهز بحوث الاراضى والمياه والبيئة - مركز البحوث الراعية - الجيزة - مصر . ملئ
}

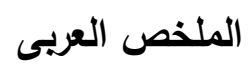

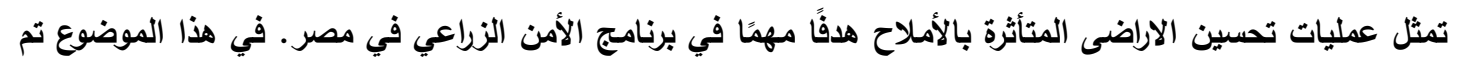

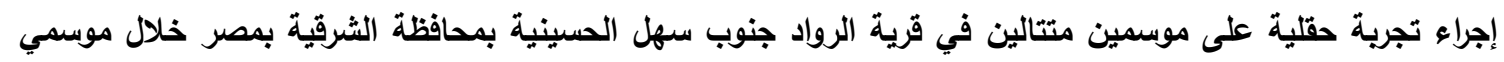

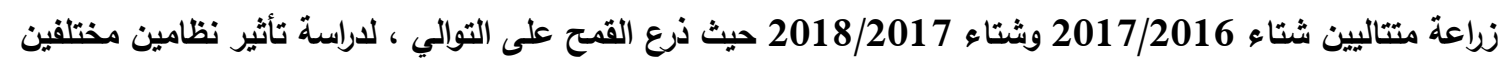

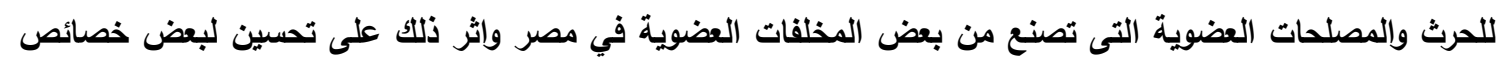

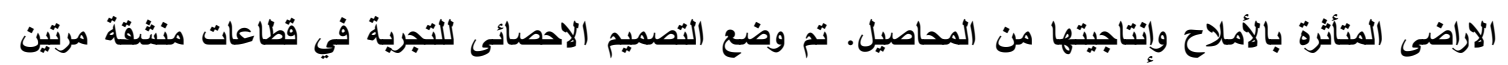

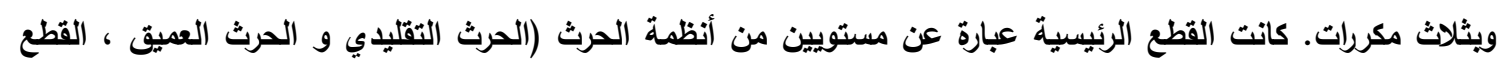

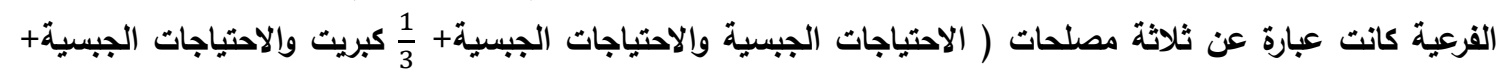
3 جبس) وكانت القطع تحت الفرعية عبارة عن مصلحين عضويين (نثارة الخثب وقش الأرز) تم توزيعهما بثكل موحد

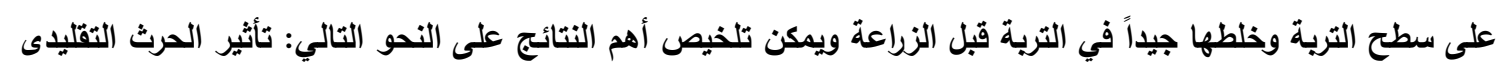

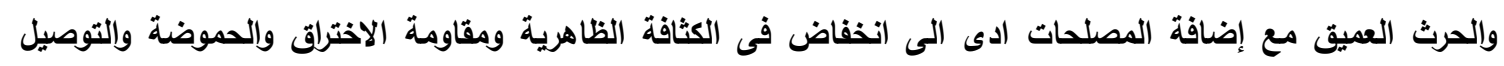

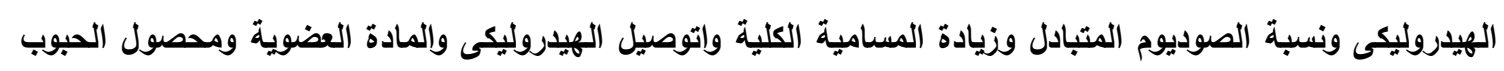

والقش

وعموما يمكن استنتاج ان الحرث العميق والجبس ونثارة الخشب قد قللت التأثير الضار لملوحة التربة ويالتالى انطبع التابع ذلك على الاثر الايجابى لنمو وإنتاج القمح.

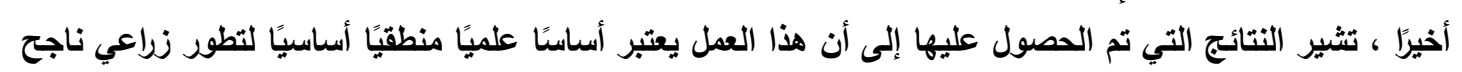
لهذه المنطقة المتأثرة بالملوحة وكذلك زيادة دخل الفتلاح.

أسماء السادة المحكمين

معهة بحوث الأراضى والمياه والبيئة- مركز البحوث الزراعية أ.د/ الحسينى عبدالنفار أبو حسين كلية الزراعة - جامعة المنوفية 